\title{
ПОЛІтОЛОГІя
}

УДК 32.019 .52

DOI https://doi.org/10.32837/apfs.v0i32.1040

\author{
Ю. В.Завгородня \\ ORCID ID: https://orcid.org/0000-0003-3500-8638 \\ кандидат політичних наук, доцент, \\ доиент кафедри політичних теорій \\ Національного університету «Одеська юридична академія»
}

\section{КІБЕРКОНФЛІКТИ ЯК ЕЛЕМЕНТ ПОЛІТИЧНИХ ТЕХНОЛОГІЙ В ІНФОРМАЦІЙНОМУ ПРОСТОРІ}

Сучасна політична система набуває глобальних масштабів, а політичні технології виходять за межі окремих регіонів. Водночас важливу роль у розвитку взаємозв'язків у політичній системі відіграють форми конфліктної активності в кіберпросторі, які серйозно впливають на економічні та політичні показники окремих регіонів світу та суттєво видозмінюють свідомість громадян.

Науково встановленим твердженням $є$ те, що інформація та комунікація є важливими елементами політичних технологій. Сучасний кіберпростір є умовним майданчиком для просування інформації в маси, а також новою формою для комунікації між політичними суб'єктами. Сучасна проблематика обраної теми полягає у відокремленні реальних політичних конфліктів в інформаційному просторі від конфліктів, які лише є формою застосування політичних технологій і не мають ціннісного значення для реальних політичних процесів та політичних дій, які є наслідком політичного протиборства. Тому в даному науковому дослідженні більш детально хочемо звернути увагу саме на комунікацію, її сучасні форми прояву, публічні методи протиборства в кіберпросторі.

Основні завдання наукового дослідження такі: проаналізувати вплив політичного конфлікту в кіберпросторі на свідомість громадян; визначити нормативний захист кіберпростору України від маніпуляцій та провокацій, які можуть бути підставою для активного конфлікту; здійснити розмежування між реальними конфліктами та вдаваними як складниками впливу на свідомість громадян; проаналізувати інформаційний простір на наявність різних форм політичного протиборства та реакцію на такі конфлікти серед свідомих громадян.

Основою наукового дослідження стали праці вітчизняних та зарубіжних авторів, а також нормативно-правові акти України, які дотичні до обраної проблематики. Значна увага приділена працям таких науковців, як: М. Ожеван, М. Пілат, А. Стадник, С. Гаврилюк, М. Вершинін, А. Казаноков, М. Закіров та інші.
Наведений перелік науковців свідчить, що питання інформаційно-комунікаційних технологій у політиці є досить актуальним та пізнавальним, а потенціал обраної тематики досить високий. Зокрема, чималий інтерес становить проблема впливу сучасних інформаційно-комунікаційних технологій на політичну сферу суспільства. Залишається актуальною роль кіберконфліктів у політичних технологіях.

3 огляду на актуальність тематики наукового дослідження, наявність завдань, які потребують обгрунтування кіберконфліктної активності в сучасних політичних процесах, які вже стають елементом політичних технологій, постає потреба у формуванні мети дослідження.

Метою є аналіз кіберконфліктів як важливої комунікаційної складової частини політичних технологій у сучасному світі.

Варто відзначити, що активна фаза конфліктної активності в кіберпросторі є частиною системи впливу на свідомість громадян і окремі групи населення з метою демонстрування ставлення окремих суб' $€$ тів політики до проблем та інтересів громадян.

На думку М. Закірова, «досягнутий натепер рівень розвитку інформаційно-комунікаційних технологій дає можливість якісно змінювати традиційні політичні інститути, на кшталт систем електронного голосування, електронного уряду тощо. Водночас змінюються форми, способи й методи політичного впливу на соціально-політичний простір як у середині держав, так і на міжнародній арені, що, у свою чергу, істотно корегує політичні відносини як такі» [1, с. 12].

Яскравим прикладом збільшення уваги до політичного лідера є його конфліктна активність. Таким яскравим прикладом в українському суспільстві є низка політичних лідерів, серед яких В. Ляшко, Ю. Тимошенко, М. Тищенко й інші. У сучасному світосприйнятті багато процесів представники політичної еліти демонструють в інформаційному середовищі через масмедіа та соціальні мережі. 
Сучасні наукові погляди концентрують увагу на трансформаціях впливу на політичну владу за допомогою інформації й інформаційних технологій. Так, на думку відомого американського науковця Е. Тоффлера, майбутні досягнення щодо політичного вдосконалення, модернізації однозначно пов'язані $з$ можливістю та бажанням вправно управляти політичною інформацією та політичними комунікаційними потоками [1, с. 12].

Політичне протиборство в мережі Інтернет може набувати різних форм, тому і механізми впливу мають бути також різними. Так, одним із різновидів політичного протиборства можна назвати зовнішні та внутрішні кіберконфлікти. Зовнішні кіберконфлікти є більш небезпечними та некерованими, оскільки сучасна міжнародна політична спільнота не може дійти єдиного правила, яке б влаштовувало сучасні країни світу та застерігало представників окремих країн від протиправних дій. Яскравим прикладом зовнішніх політичних конфліктів можна назвати міждержавні конфлікти у формі хакерських атак, які виводять 3 ладу цілі корпорації, установи, організації, тим самим показують неспроможність політичних суб'єктів захистити населення, яке в майбутньому відчує наслідки таких дій для економічної спроможності, що позначиться на індексі платоспроможності. Окрім того, зовнішні кіберконфлікти можуть мати конкретних суб'єктів протиборства, коли політичні лідери публічно в соціальних мережах роблять офіційні політичні заяви про конкретних опонентів або цілі політичні групи, погляди яких є діаметрально протилежними та потребують публічного обговорення на міжнародному рівні.

Сучасні ЗМІ перед збором інформації для новин стежать за всіма соціальними сторінками політичних діячів, лідерів політичних груп, які оприлюднюють політичні заяви через соціальні мережі. Соціальні мережі стали офіційним джерелом інформації щодо політичних дій та рішень, однак притягнути до відповідальності за недостовірність чи необ'єктивність такої інформації в українському суспільстві дуже важко.

Що стосується внутрішніх кіберконфліктів, то до них варто віднести саме публічні мережеві висловлювання різних політичних сил, які мають важелі впливу в політиці та зацікавленні в лобіюванні окремих політичних рішень.

Саме політичне протиборство в кіберпросторі $е$ абсолютно новою формою взаємодії для політичних акторів в Україні, отже, і новим механізмом впливу на політичні процеси. Тому політикам часто доводиться просити вибачення за емоційні чи необдумані дописи та відео в інтернеті, що також формує політичну свідомість активних інтернет-користувачів України.

Оскільки на міжнародному рівні діють лише загальнолюдські принципи, щодо правил співіс- нування у світі різних релігій, політичних ідеологій, моральних переконань, життєвих настанов, які виокремлюють форми та методи сучасного світу і не встановлюють дієвого механізму боротьби 3 такими загрозами, то окремим державам варто діяти хоча б індивідуально. Адже на свідомість політичних лідерів та хакерів не доводиться покладатися. Тому що політичні амбіції можуть бути сильніші за будь-які принципи, навіть у зразкових країнах світу. Яскравим прикладом такої діяльності є США - прогресивна країна світу. Коли дописи Дональда Трампа були видалені соціальними мережами як такі, що не відповідають інформаційній політиці їхніх сайтів.

Українська держава перебуває на етапі формування механізму захисту кіберпростору та створення механізму відповідальності за кіберзлочини, які можуть мати і політичні ознаки, щодо приниження честі та гідності політичних діячів або щодо повалення національного ладу через проголошення антинаціональних лозунгів та гасел конкретними політичними лідерами чи представниками політичних партій, які офіційно зареєстровані відповідно до Закону України «Про політичні партії в Україні" (https://zakon.rada.gov.ua/laws/show/2365-14\#Text)[5].

Для деталізації поняття кіберконфлікту варто розуміти, що він наділений такими характеристиками, які відрізняють його від інших видів активності в інтернеті, які містять негативний напрям сприйняття. У сучасному інтернет-просторі існує таке поняття, як «кібербулінг», яке має елементи назрівання конфлікту, однак обмежується переважно відносинами щодо цькування підлітків, тому для активності в політичних процесах щодо політичних рішень і суспільно значущих подій доцільно вживати саме поняття «політичне кіберпротиборство, або кіберконфлікт» .

Окрім того, варто пам'ятати, що в сучасному українському політичному протиборстві існують елементи змішаних форм політичного впливу на опонента, так, політичний лідер може висловлюватись щодо ухвалення політичних рішень на власних офіційних сторінках у соціальних мережах, це буде сприйматись як офіційне бачення політика та політичної сили, представником якої він $є$, однак, якщо політична партія не підтримує погляди окремого політичного діяча, вона вдається до конкретних політичних важелів впливу вже за межами інформаційного простору.

Яскравим прикладом змішаної форми протиборства можна назвати політичну діяльність та публічні висловлювання народного депутата України 9-го скликання Верховної Ради України Олександра Дубінського - представника політичної партії та фракції «Слуга народу». Наслідком його індивідуалістської політичної діяльності стала політична відповідальність у формі 
виключення його із фракції «Слуга народу» 1 лютого 2021 р., а вже 15 березня його було виключено 3 політичної партії «Слуга народу», підставу для звільнення публічно оголошено як «порушення Статуту та непокору керівним органам партії». Отже, бачимо, що наслідки політичних публічних дій мають чітку правову площину, яка регламентована статутом партії та законами України «Про політичні партії» [5], «Про регламент Верховної Ради України» [6], однак водночас і політичну міру відповідальності.

Тому, зважаючи на особливості функціонування політичної системи, форм взаємодії політичних суб'єктів, можемо спостерігати значущість активної інформаційної діяльності депутатського корпусу та представників органів державної влади, які висвітлюють політичні процеси й ухвалені політичні рішення в соціальних мережах, які стають частиною політичного спілкування сучасного політика, елементом впливу на політичні процеси, що можна тлумачити як сучасну форму політичних технологій.

Новою формою спілкування із громадянами користується президент України, який на власних офіційних сторінках повідомляе всі новини, які мають суспільне значення. Окрім того, більшість публічних осіб та політиків користуються послугами не лише помічників із різних галузей, щодо державотворчих процесів, а й відповідальних за публікації на офіційних сторінках в інформаційних мережах осіб. Така тенденція показує значущість інформаційного простору для політико-соціального спілкування, хоча вона також не є досконалою й ефективною для того, щоб політики дослухались до громадянської думки.

Однак таке спілкування повинно відбуватись у політико-правових межах, а тому Президентом України ухвалений Указ «Про Стратегію кібербезпеки України» від 15 березня 2016 р. № 96/2016, яким установлено, що «метою Стратегії кібербезпеки України є створення умов для безпечного функціонування кіберпростору, його використання в інтересах особи, суспільства і держави. Для досягнення цієї мети необхідними є: створення національної системи кібербезпеки; посилення спроможностей суб'єктів сектору безпеки та оборони для забезпечення ефективної боротьби з кіберзагрозами воєнного характеру, кібершпигунством, кібертероризмом та кіберзлочинністю, поглиблення міжнародного співробітництва в цій сфері; забезпечення кіберзахисту державних електронних інформаційних ресурсів, інформації, вимога щодо захисту якої встановлена законом, а також інформаційної інфраструктури, яка знаходиться під юрисдикцією України та порушення сталого функціонування якої матиме негативний вплив на стан національної безпеки і оборони України (критична інформаційна інфраструктура)» [7].
На розвиток системи інформаційного захисту депутатами України у 2017 р. ухвалений закон для захисту кіберпростору України та введення у правову площину спілкування різного виду, зазначено способи хакерських атак, які можуть негативно впливати на політичні процеси. Закон України «Про основні засади забезпечення кібербезпеки України" [8] регламентує правові й організаційні особливості здійснення захисту життєво важливих пріоритетів людини і громадянина, окремої громади та держави загалом, інтересів української нації в кіберпросторі, основні цілі, вектори та принципи державної діяльності у сфері кібербезпеки, повноваження представників влади, підприємств та громадян у цьому напрямі, основні засади спрямування їхньої діяльності 3 реалізації основ кібербезпеки.

$\mathrm{У}$ цей нормативно-правовий акт уже внесені зміни щодо формулювання окремих норм (2018, 2020 та 2021 рр.), що демонструє потребу в подальшому вдосконаленні й актуалізації даного напряму державної діяльності, зі збільшенням кількості операцій підприємств в електронних системах, можливості проведення електронних транзакцій, можливості подання електронних заяв та звернень цей напрям потребує подальшого вдосконалення для забезпечення захищеності в інформаційній системі.

Адже рівень розвитку українського суспільства залежить від рівня захисту його громадян. Надійна політико-правова система допомагає вдосконалювати економічно-інтелектуальний потенціал та забезпечувати стабільний розвиток для держави, отже, і для населення.

Кіберпростір для політичної системи є не лише місцем політичних технологій, тобто місцем впливу на свідомість та політичні процеси, це також платформа для політичного маркетингу, де відбувається відповідна реклама послуг, які може надати кожен окремий політик чи політична сила, яку він представляс. Тому в такому форматі простіше отримати доступ до характеристик політичного діяча, власних політичних позицій та публічних форм взаємодії.

На думку М. Закірова, «опанування інформаційних технологій, можливість керувати інформацією й інформаційними потоками вже стали одним із головних важелів політичної влади. В епоху інформаційного суспільства саме можливість генерувати і транслювати політичну інформацію, здійснюючи ефективний інформаційний вплив, у поєднанні з наявністю спеціальних механізмів та інститутів, які можуть робити це цілеспрямовано й успішно, визначає результативність державної політики як у середині країни, так і на міжнародній арені» [1, с. 30].

Водночас, визначаючи значну роль інформаційно-комунікаційних потоків у політичних 
технологіях, можемо дійти висновків щодо ролі кіберконфліктів у використанні маніпуляційного впливу на політичну свідомість у суспільстві. Для досягнення конкретного результату суб'єкти політики вдаються до різних форм та методів, які сприяють задоволенню їхніх інтересів та продовжують їхне політичне активне життя. Конфлікти в кіберпросторі є невід'ємним елементом для використання як політичних технологій.

Ознака конфліктності політичного діяча в політичних процесах не ставить на ньому тавра поганої людини, оскільки більшість політичних рішень у процесі ухвалення спричиняють суперечки та конфронтацію між політичними групами, а емоційність та імпульсивність часто сприймаються як глибока занепокоєність політичного лідера проблемами в суспільстві.

Проте не варто переоцінювати можливості окремо взятого політичного діяча, оскільки у відкритих демократичних державах роль одного політичного лідера не вагома в ухваленні серйозних суспільно важливих питань, лише ідеологічні об'єднання дають результат ефективної політичної роботи.

Такі об’єднання за принципами й ідеологією створюються не лише на державному рівні, а й на наддержавному рівні, оскільки межі політичних технологій, межі застосування політичного впливу розширюються глобально, то відповідно виникає потреба у згуртуванні суб'єктів політики у вирішенні політичних питань, а також урегулюванні конфліктів, які виходять за національні межі.

У сучасному інформаційному просторі спостерігається велика кількість публічних політичних протиборств, які є вагомим чинником під час ухвалення політичних рішень, одні стають формою маніпуляції політичною свідомістю, інші формують об'єктивну картину політичних процесів. Така політична дійсність формує гібридні форми взаємодії в політичній системі та провокує політичних діячів до творення базових орієнтирів, якими варто керуватись під час політичної діяльності й участі в конфліктній взаємодії.

Сучасному суспільству, як і політичним діячам, варто перелаштуватися під нові форми активності та публічної діяльності в інформаційному просторі, які організовують наддержаний рівень уваги до суб'єктів конфліктної активності та формують міжнародний імідж, а вотже, і рівень політичної значущості.

\section{Jimepamypa}

1. Закіров М. Сучасні інформаційно-комунікаційні технології як фактор еволюції соціально-політичних відносин. Наукові праці Національної бібліотеки України ілені В.I. Вернадського : збірник. 2017. № 46. С. $11-30$.

2. Ожеван М. Основні напрями зовнішніх інформаційно-маніпулятивних впливів на суспільні трансфор- мації в Україні: засоби протидії. Стратегічні пріоритети. 2011. № 3. С. 118-126.

3. Пілат М. Інформаційні впливи та інформаційні війни: сутність понять та їхній взаємозв'язок в інформаційну епоху. Вісник Львівського університету. Сeрія «Міжнародні відносини». 2013. №. 32. С. 185-190.

4. Стадник А. Інформаційна війна, як комунікативна технологія впливу на масову свідомість та громадську думку. Грані. Соціологія. 2016. № 1. С. 111-115.

5. Про політичні партії в Україні : Закон України від 5 квітня 2001 р. № 2365-III / Верховна Рада України. URL: https://zakon.rada.gov.ua/laws/show/236514\#Text (дата звернення: 25.10.2021).

6. Про регламент Верховної Ради України : Закон України від 10 лютого 2010 р. № 1861-VI / Верховна Рада України. URL: https://zakon.rada.gov.ua/cgi-bin/ laws/main.cgi?nreg=1861-17\#Text (дата звернення: 25.10.2021).

7. Про рішення Ради національної безпеки i оборони України від 27 січня 2016 р. «Про Стратегію кібербезпеки України» : Указ Президента України від 15 березня 2016 р. № 96/2016. URL: https://www.rnbo.gov.ua/ua/Ukazy/417.html?PRINT (дата звернення: 25.10.2021).

8. Про основні засади забезпечення кібербезпеки України : Закон України від 5 жовтня 2017 р. № 2163-VIII / Верховна Рада України. URL: https://zakon.rada.gov.ua/laws/show/2163-19\#Text (дата звернення: 25.10.2021).

\section{Анотація}

Завгородня Ю. В. Кіберконфлікти як елемент політичних технологій в інформаційному просторі. Стаття.

Протиборство сучасних політичних акторів набуває нових форм та проявів. Впливові політичні лідери виходять за територіальні межі окремих країн, політичних організацій та міжнародних громадських об'єднань та стають не лідерами окремих регіонів чи країн, а світовими флагманами політичного та державного управління. Сучасна світова спільнота здійснює суттєвий вплив на бачення громадян під час вибору нового політичного лідера країни або окремого регіону, області чи міста, що формує новітні форми поглядів, думок та завоювання популярності політичними лідерами. А тому в сучасних формах взаємодії між суб'єктами політики пріоритетні відкриті переговори, які доступні для публічного суб’єктивного сприйняття.

Демократичне суспільство здійснює аналіз політичних форм взаємодії, оцінює та робить власні висновки щодо подальших індивідуальних та стратегічних глобальних дій у суспільстві. Оскільки тренди та пріоритети в суспільстві змінюються, змінюється політична форма активності з метою зацікавлення більшої кількості громадян. Сучасний напрям публічної взаємодії та також i протиборства суб'єктів політики - інтернет-простір, за допомогою якого політичні діячі все частіше говорять про власні досягнення та поразки або не дороблені справи опонентів. 
Істотно впливає на спроможність власного самовираження як суб'єкта політико-правових ефективна структура кіберпростору як дієвого механізму для політичної активності та впливу на свідомість громадян, через пропаганду суб'єктивних ідеологічних поглядів, які обстоюють інтереси зацікавлених груп, регіонів або індивідів, які матеріально спроможні залучати інформацію в маси та формувати план ефективного політичного розвитку. Така діяльність є новим чинником дії політичних технологій, які набувають новітніх форм прояву у зв'язку зі зміною публічних локацій для політичних акторів.

Ключові слова: кіберконфлікти, політичні технологіі, інформаційний простір, кіберпростір, протиборство, маніпуляції, інформаційні мережі.

\section{Summary}

Zavgorodnya $\mathrm{Yu}$. V. Cyberconflicts as an element of political technologies in the information space. - Article.

The confrontation of modern political actors takes on new forms and manifestations. Influential political leaders go beyond the territorial boundaries of individual countries, political organizations and international public associations and become leaders not of individual regions or countries, but of world flagships of political and public administration. The modern world community has a significant impact on the vision of citizens when choosing a new political leader of a country or a particular region, region or city, which forms the latest forms of views, opinions and gaining popularity by political leaders. Therefore, in modern forms of interaction between policy actors, priority is given to modern open negotiations, which are available for public subjective perception.

A democratic society analyzes political forms of interaction, evaluates and draws its own conclusions about further individual and strategic global actions in society. As trends and priorities in society change, so does the political form of activity in order to interest more citizens. The modern direction of public interaction and also the confrontation of political actors is the Internet space, through which politicians increasingly talk about their own achievements and defeats, or unfinished business of opponents.

An effective structure of cyberspace, as an effective mechanism for political activity and influence on the consciousness of citizens, through the promotion of subjective ideological views that defend the interests of stakeholders, regions or individuals has a significant impact on the ability to express themselves as a subject of political and legal relations, who are financially able to attract information to the masses and form a plan for effective political development. Thus, activity is a new factor in the action of political technologies, which are gaining new forms of manifestation in connection with the change of public locations for political actors.

Key words: cyberconflicts, political technologies, information space, cyberspace, confrontation, manipulations, information networks. 